\title{
FAMILY PROTECTION IN CENTRAL EUROPEAN COUNTRIES
}

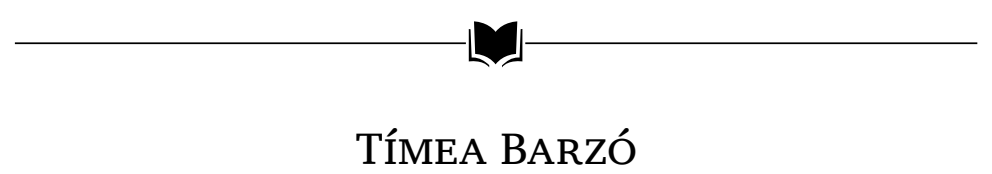

\section{Introduction}

This volume presents the family law and protection systems of seven Central European countries (Croatia, Czech Republic, Hungary, Poland, Serbia, Slovakia, and Slovenia). This article is a summary of the relevant legal regulations in force in the abovementioned countries. As this chapter is a synthesis, it was written based on the country reports that comprise this volume. Consequently, there are no scientific, literature-related references, or footnotes in this article. Only the Acts and other legal sources are indicated in the footnotes. A part of the article deals with the legal environment concerning this topic. If the reader is interested in the sources and a more detailed analysis of the legal institutions and solutions involved, they may read the relevant country reports. We did not aim to present the countries in alphabetic order, but rather prioritized a comprehensive approach. Therefore, we composed the article according to a logical line where similarities and differences dominate in relation to the given legal institutions. We present an overview of the topic in five parts from a comparative perspective. The legal basis, definition of family, relationship forms, descendant relationships, and the parent-child relationship are presented.

Tímea Barzó (2021) Family Protection in Central European Countries. In: Tímea Barzó, Barnabás Lenkovics (eds.) Family Protection From a Legal Perspective, pp. 287-322. Budapest-Miskolc, Ferenc Mádl Institute of Comparative Law-Central European Academic Publishing. 


\section{The structure of the legal basis}

\subsection{Constitutional protection}

The constitutional protection of a legal field has utmost importance because it constitutes the legal basis of the legal institutions governing the field in question. Many basic features can be ascertained in relation to a given legal area if we analyze the relevant regulations of the country's Constitution. The constitution forms the basic law of each Central European country. If we take a deep dive into the regulations under each country's constitution, we can see that all of them establish a constitutional framework that aims to protect the family.

In the Constitution of the Slovak Republic ${ }^{1}$ there are no legal alternatives to marriage. This is rooted in the perspective governing Slovak family law, which emphasizes on the biological reproductive functions of the family. According to Article 41 of the Constitution, "Marriage is a unique bond between a man and a woman. The Slovak Republic broadly protects and promotes its good. Marriage, parenthood and the family are under the protection of the law." We will examine this in detail in this chapter. A deeper analysis is presented in the Slovak country report as well. The family law regime in Slovakia does not recognize same-sex or non-traditional forms of marriage. It does not define or protect cohabitation, either. A similar approach is seen in the Constitution of The Republic of Serbia, ${ }^{2}$ as well. The Serbian Constitution emphasizes that marriage and family are universal human rights and fundamental values. It declares that, " $E v$ eryone shall have the right to decide freely on entering or dissolving a marriage. Marriage shall be entered into based on the free consent of man and woman before the state body." In the Serbian Constitution, the protection of family relations and parents are merged. It stipulates that families, mothers, single parents, and any children in the Republic of Serbia shall enjoy special protection in accordance with the law. This legal protection incorporates a special support and protection mechanism for mothers before and after childbirth and for children without parental care and/or with impediments to their mental and/or physical development. According to the Serbian Constitution, non-marital cohabitation shall be equal to marriage. The definition of non-marital cohabitation is found in the Family Law Act. The Constitution of the Republic of Poland ${ }^{3}$ contains only a few provisions on family. However, it emphasizes that marriage is contracted between a woman and a man. The privacy of family life and the right to make decisions on personal life are subject to Polish constitutional protection. Besides the privacy of family life, the protection of children is also of great importance, specifically with respect to the children's right to a hearing in proceedings and for their views to be taken into account, and for children who are deprived of parental care.

1 Constitution of the Slovak Republic of 1992 (460/1992 Coll.)

2 Constitution of the Republic of Serbia, Official Gazette of Serbia no. 98/06.

3 The Constitution of Poland, April 2, 1997. 
We can read about the concrete protection of family and parenthood in the Czech Charter of Fundamental Rights and Freedoms ${ }^{4}$, because it declares thus: "Parenthood and the family are under the protection of the law" (Article 32, Section 2). A family based only on marriage is not mentioned there, but there is a draft amendment that intends to modify the text as follows: "Parenthood, the family and marriage as a union of a man and a woman are under the protection of the law". ${ }^{5}$

Most of these Constitutions consider marriage a basic unit of family. Article 62 of the Croatian Constitution ${ }^{6}$ provides thus: "The marriage is a union of a woman and a man" and adds that "The marriage and legal relationships in the marriage, nonmarital union and family shall be regulated by law". According to Article 53(2) of the Slovenian Constitution, ${ }^{7}$ legal relations within the family must be regulated by law. However, there is a unique solution under Slovenian law. Cohabitation is also mentioned as follows: "law shall regulate legal relations in an extramarital union (cohabitation)." The Slovenian Constitution offers rather detailed regulations and principles regarding marriage, as it declares that marriage shall be based on the equality of the spouses and shall be solemnized before an empowered state authority (Article 53(1)). Unlike other constitutions, we can see a more open approach in that the Slovenian Constitution emphasizes on the equality of spouses, but does not assume their gender diversity. The Fundamental Law of Hungary ${ }^{8}$ states that "the basis of the family relationship is marriage or the parent-child relationship".

The table below summarizes the constitutional protection mechanisms

\begin{tabular}{|c|l|}
\hline Country & \multicolumn{1}{c|}{ Constitutional protection } \\
\hline Slovakia & $\begin{array}{l}\text { Constitution of the Slovak Republic of } 1992 \text { (460/1992 Coll.) } \\
\text { There are no legal alternatives to marriage. } \\
\text { Article } 41 \text { of the Constitution states that "Marriage is a unique bond between } \\
\text { a man and a woman." Marriage, parenthood, and the family are protected by } \\
\text { the law. }\end{array}$ \\
\hline Serbia & $\begin{array}{l}\text { Constitution of the Republic of Serbia, Official Gazette of Serbia No. } 98 / 06 \\
\text { Marriage and family are universal human rights and fundamental values } \\
\text { Families, mothers, single parents, and any child in the Republic of Serbia } \\
\text { shall enjoy special protection } \\
\text { Non-marital cohabitation shall be equal to marriage, but the definition of } \\
\text { non-marital cohabitation can only be found in the Family Law Act }\end{array}$ \\
\hline
\end{tabular}

4 Act No. 2/1993 Coll.

5 Parliament of the Czech Republic, Chamber of Deputies, Parliamentary term No. VIII., Draft No. 211/0.

6 Consolidated text, Official Gazette Nos 56/90, 135/97, 113/00, 28/01, 76/10 and 5/14.

7 Constitution of the Republic of Slovenia. Official Gazette of the Republic of Slovenia Nos. 33/91-I, 42/97, 66/2000, 24/03, 69/04, 68/06, and 47/13.

8 Fundamental Law of Hungary (25 April 2011). 


\begin{tabular}{|c|l|}
\hline Country & \multicolumn{1}{c|}{ Constitutional protection } \\
\hline Poland & $\begin{array}{l}\text { The Constitution of April 2, 1997 } \\
\text { Contains only a few provisions on family } \\
\text { Privacy of family life and the right to make decisions on personal life are } \\
\text { subject to constitutional protection } \\
\text { Protection of children } \\
\text { Marriage is contracted between a woman and a man }\end{array}$ \\
\hline Czech & $\begin{array}{l}\text { Charter of Fundamental Rights and Freedoms (Act No. 2/1993 Coll.) } \\
\text { Parenthood and family are under the protection of the law. }\end{array}$ \\
\hline Croatia & $\begin{array}{l}\text { Consolidated text of the Constitution, Official Gazette Nos 56/90, 135/97, } \\
113 / 00,28 / 01,76 / 10 \text { and 5/14 } \\
\text { Marriage is a union between a woman and a man } \\
\text { Marriage and legal relationships arising out of marriage, non-marital unions, } \\
\text { and families shall be regulated by law }\end{array}$ \\
\hline Slovenia & $\begin{array}{l}\text { Constitution of the Republic of Slovenia. Official Gazette of the Republic of } \\
\text { Slovenia Nos. 33/91-I, 42/97, 66/2000, 24/03, 69/04, 68/06, and 47/13 } \\
\text { Legal relations within the family shall be regulated by law } \\
\text { Cohabitation is mentioned in the Constitution: "The law shall regulate legal } \\
\text { relations in an extramarital union (cohabitation)." } \\
\text { Open approach } \\
\text { Principles regarding marriage }\end{array}$ \\
\hline Hungary & $\begin{array}{l}\text { Fundamental Law of Hungary (25 April 2011) } \\
\text { Basis of the family relationship is marriage or the parent-child relationship }\end{array}$ \\
\hline
\end{tabular}

\subsection{The relationship between Family and Civil Laws}

One of the most important questions regarding the systematic approach to family law is whether it is an integral part of the domestic Civil Code or is regulated under a separate act. In the legal system of the aforementioned Central European countries, we can find samples for both situations. The systematic positioning of family law can change in the course of legal development. For example, in Hungary, Family Law was regulated by a separate act, namely the former Family Law Act ${ }^{9}$ for a long time. However, when the current Civil Code ${ }^{10}$ was adopted in 2013, the family law rules became an integral part of the "new" Civil Code, known as Book V. In contemporary Hungary, family law is a part of the Civil Code, but there are several Acts and legal sources that supplement the overall system. The Czech legal system is similar. The 
new Civil Code was adopted in $2012^{11}$ and Family Law was integrated into the Civil Code - Book Two. The basic principles, values, starting points, interpretations, and rules can be found in Book One - General Part. As the Civil Code emphasizes, like the Hungarian one, the autonomy of the will is fully manifested in Family Law as well, especially in the context of marital property law. In other Central European countries, family law is regulated by a separate Act.

In the socialist era (1945-1990) in Croatia, family law was separated into a specific legal field distinct from civil law, and remained thus in the transitional and post-transitional periods. The currently effective primary legal source of family law is the Family Act of $2015^{12}$. Poland also has a separate act, namely the Family and Guardianship Code, ${ }^{13}$ which governs family law affairs. Similarly, family relations in the Slovak legal system are regulated by the Family Act. ${ }^{14}$ Since 1950, family relations have been set outside the scope of the Civil Code and are still regulated by a separate law. Unless the Family Act provides otherwise, the provisions of the Civil Code apply to family relationships. In the Slovak legal environment, the basic principles of family law are listed in the Constitution. In Serbia, the Family Act ${ }^{15}$ regulates families. A fresh legal source operates in Slovenia, where the new Family Code entered into force in April 2019, which replaced the Marriage and Family Relations Act, which was over 40 years old at the time. Further, the Civil Unions Act and NonContentious Civil Procedure Act were adopted. All three laws represent the pillars of contemporary Slovenian family law. Family law is governed by separate legislation in most of Central European countries. However, it remains an integral part of the Civil Code in the Czech Republic and Hungary alone.

The table below outlines the relationship between family and civil laws

\begin{tabular}{|c|l|}
\hline Country & \multicolumn{1}{|c|}{ Relationship between family and civil laws } \\
\hline Hungary & Family law rules became an integral part of the Civil Code in 2013 \\
\hline $\begin{array}{c}\text { Czech } \\
\text { Republic }\end{array}$ & Family Law was integrated into the Civil Code in 2012 \\
\hline Croatia & Separate Family Act from 2015, not an integral part of the Civil Code \\
\hline Poland & $\begin{array}{l}\text { Separate act, the Family and Guardianship Code, not an integral part of the } \\
\text { Civil Code }\end{array}$ \\
\hline Slovakia & Separate Family Act, not an integral part of the Civil Code \\
\hline
\end{tabular}

11 See the Act No. 89/2012 Coll., Civil Code.

12 Family Act, Official Gazette Nos. 2013/2015 and 98/2019.

13 Act of 25 February 1964 the Family and Guardianship Code, ct. Journal of Laws 2020, item 1359.

14 Act No. 36/2005 on Family and on amendment of some other acts.

15 Official Gazette of Serbia 18/05. 


\begin{tabular}{|c|l|}
\hline Country & \multicolumn{1}{|c|}{ Relationship between family and civil laws } \\
\hline Serbia & Separate Family Act, not an integral part of the Civil Code \\
\hline Slovenia & Separate Family Act, not an integral part of the Civil Code \\
\hline
\end{tabular}

\subsection{Other legal sources}

In the legal systems of the countries analyzed, other legal documents were significant, too. We can find, for example, administrative laws and acts dealing with the protection of family relationships from the perspective of criminal law. In countries where same-sex relationships are regulated by law, separate laws govern the legal aspects of such relationships.

The proper legal terminology used to refer to same-sex partnerships varies by country. For example, in the Czech Republic and Hungary, the term used is "registered partnership." In Croatia, the term "same-sex life partnership" is used. In Slovenia, the term "civil union" is used (earlier, the term used was "registered same-sex civil partnership"). In the Croatian legal system, the Same-Sex Life Partnership Act $(2014)^{16}$ recognizes same-sex partnerships. Other laws also deal with different aspects of family protection, such as the Act on Protection against Violence in Family ${ }^{17}$, Foster Care $\mathrm{Act}^{18}$, and the Act on Medically Assisted Reproduction.

Besides the Civil Code, the Act on Registered Partnership ${ }^{19}$ operates as a separate source of family law in the Czech legal system. It is quite similar to the Hungarian legal system, because family law is incorporated in the Civil Code and registered partnerships are governed by separate laws. Thus, the rules regulating the rights and duties of same-sex partners were not incorporated into the Civil Code. However, according to the country report, a pending draft submitted by a group of deputies before the Parliament of the Czech Republic is in favor of gender-neutral marriages. ${ }^{20}$ In parallel, another pending draft was lodged by another group of deputies that aims to protect the traditional family model. In Slovenia, the Civil Unions Act was adopted in 2016. It introduced a new term, namely "civil union," and replaced the former term "same-sex civil partnerships," which was regulated by the previous Act on Registered Same-sex Partnerships. According to the Civil Union Act, civil unions can be entered into by two people of the same sex and this Act, like the Family Code, which governs marriage as a union of two persons of different sexes, is based on the principle of monogamy. In Slovenia, several other laws contain provisions interfering

16 The Same-Sex Partnership Act, Official Gazette Nos. 92/2014 and 126/2019.

17 The Act on Protection against Violence in Family, Official Gazette Nos. 70/2017, and 126/2019.

18 Official Gazette 115/2018.

19 See the Act No. 115/2006 Coll.

20 Parliament of the Czech Republic, Chamber of Deputies, Parliamentary term No. VIII., Draft No. 201/0. 
with family law relations, such as the Domestic Violence Act, the Criminal Code, and the Foster Care Act.

In Hungary, Act XXIX of 2009 on registered partnerships and the amendment of the proof of cohabitation relationship was enacted in 2009. It continues to remain in force. Registered partnerships has been completely removed from the Civil Code. The Act does not mention the term in the definition of "relative" and in the list of impediments to marriage. It can only be found in circumstances that preclude the existence of effective cohabitation. However, this does not mean that registered partners have fallen out of the protection zone of the Civil Code, as the Act on Registered Partnerships says that the rules on marriage shall be applied to registered partnerships with exceptions regulated by law. Registered partners have all the rights and obligations that are attached to marriage in relation to personal and property rights and obligations under the Civil Code. The Acts on the Protection of Families (2011), the Register Procedure (2010), and the Civil Procedure (2016) also regulate families. In Serbia, there is no law governing same-sex partnerships. However, a Draft Law is under preparation. In Slovakia, the law does not recognize same-sex partnerships. Polish law is similar to Slovak law, as homosexual couples are not allowed to marry or conclude registered partnerships. In Poland, among many legal sources of family protection, the most important ones are: the Act on Supporting the Family and the System of Foster Care, the Alimony Support Act, the Act on Pensions and Old-Age Pensions from the Social Insurance Fund, as well as the Civil, Civil Procedure, and Criminal Codes.

The most significant legal sources are listed in the table below

\begin{tabular}{|c|l|}
\hline Country & \multicolumn{1}{|c|}{ Law on same-sex partnership and other important legal sources } \\
\hline Croatia & $\begin{array}{l}\text { Same-Sex Life Partnership Act } \\
\text { Act on Protection against Violence in the Family } \\
\text { Foster Care Act } \\
\text { Act on Medically Assisted Reproduction }\end{array}$ \\
\hline $\begin{array}{c}\text { Czech } \\
\text { Republic }\end{array}$ & $\begin{array}{l}\text { Civil Code } \\
\text { Act on Registered Partnership } \\
\text { Two opposing drafts }\end{array}$ \\
\hline Slovenia & $\begin{array}{l}\text { Civil Unions Act } \\
\text { Family Code } \\
\text { Domestic Violence Act } \\
\text { Criminal Code } \\
\text { Foster Care Act }\end{array}$ \\
\hline
\end{tabular}




\begin{tabular}{|c|l|}
\hline Country & \multicolumn{1}{|c|}{ Law on same-sex partnership and other important legal sources } \\
\hline Hungary & $\begin{array}{l}\text { Act on Registered Partnership } \\
\text { Civil Code (Family Law Book, Law of Obligation Book, Succession Law Book) } \\
\text { Act on the Protection of Families } \\
\text { Act on the Register Procedure } \\
\text { Act on Civil Procedure }\end{array}$ \\
\hline Serbia & $\begin{array}{l}\text { Draft law on same-sex partnership } \\
\text { Family code }\end{array}$ \\
\hline Slovakia & $\begin{array}{l}\text { No legal regulations govern same-sex partnerships } \\
\text { Family Act }\end{array}$ \\
\hline $\begin{array}{l}\text { No legal regulation on same-sex partnerships } \\
\text { Act on Supporting the Family and the System of Foster Care } \\
\text { Alimony Support Act } \\
\text { Act on Pensions and Old-Age Pensions from the Social Insurance Fund } \\
\text { Civil Code } \\
\text { Civil Procedure Code } \\
\text { Criminal Code. }\end{array}$ \\
\hline
\end{tabular}

\section{The conceptual approach to family}

Conceptual approaches and legal definitions are important from the perspective of legal research. Thus, it is worth engaging in a conceptual analysis of the central element of a given topic. Accordingly, this section analyses the legal definition of family, which remains in transition between the perspectives of private and public law. Nor the international legal documents contain a proper legal definition of family. It is not common to articulate concrete legal definitions in the laws of Central European countries. Thus, it is not easy to provide a legal definition for the term "family", although the word seems easy to understand. However, we study two exceptions, as the Hungarian and Slovenian legal systems define the term.

Generally, "family" can be considered a natural and basic component of a society that represents unity. Croatian family law has become a separate legal discipline under civil law. Croatian law has not provided a legal definition for the term "family" yet. The Croatian legal literature acknowledges that there are many forms of families in a sociological sense and emphasizes that it is not possible to define the term clearly within the legal framework of family law. The same is true of the Czech legal system: there is no definition for the term family and family members in the Czech Civil Code, either. However, the First Book of the Czech Civil Code, 
which is the General Part, expressly protects families established by marriage. Polish law does not define family in a legal sense, but the country report emphasizes that a conceptual approach to understanding the term shall be analyzed from different perspectives. The prevailing position in the Polish doctrine is that there is no need to create a legal definition that would apply to all regulations concerning the functioning of this social group.

None of the other countries' laws define the term "family," because family law regulates family relations and relations among family members. Thus, the family itself is generally not the holder of rights and duties, but enjoys civil and social protection under the Constitution. A precise definition of the term would result in restrictions. Family relations develop quickly. Consequently, new forms of family that were unknown in the past have now emerged. Thus, it would be impossible to formulate an appropriate definition for the term. Slovak family law was not uniformly regulated or codified until 1949, and it did not define the term either. Since 1950, family relations were not stipulated by the Civil Code but by a separate law.

The Slovenian and Hungarian family laws define the term "family." According to Slovenian law, marriage is the main form of family. However, over the last 30 years, the number of families based on extramarital unions has grown. The Slovenian Family Code defines the term "family" in broad terms, as an important social institution that enjoys special protection. It is a living community of a child, regardless of the child's age, with both or one parent or another adult, provided that the adult cares for the child and has certain obligations and rights toward the child. The child is central to the interpretation of the term "family" in Slovenian family law. It is based on an integral approach and is recognized in the Family Code as an important social institution that enjoys special protection. Article 2 of the Family Code is supported by Article 3(2) of the Family Code, which sees the importance of marriage in conceiving a family.

Hungarian law also defines the term "family." Besides the Fundamental Law, the Act on the Protection of Family stipulates that raising children in a family is safer than any other option. A family can fulfill its role if there is a strong relationship between the mother and father, which, in turn, completely expands to cover the responsibility owed to the child. Before the Fourth Amendment of the Basic Law, the term "family" covered both families based on marriage and those in a sociological sense. The body established the unconstitutionality of the sections of the Family Protection Act defining the term "family". Since 2012 the definition of the family relationship based on marriage was included only in the Family Protection Act, which is at a lower level of legal source. The contradiction was resolved by the Fourth Amendment of the Basic Law, which states thus: "the basis of the family relationship is marriage or the parent-child relationship". However, this definition de facto excludes partnerships and children born out of this relationship from the scope of family and, indirectly, family protection. 
The table below summarizes the conceptual approach to the term "family"

\begin{tabular}{|c|c|}
\hline Country & Conceptual approach \\
\hline Croatia & $\begin{array}{l}\text { No definition of family. } \\
\text { In the legal literature, family "is constituted by a group of people who are } \\
\text { related among themselves based on kinship marriage or any other legally } \\
\text { relevant point of reference." }\end{array}$ \\
\hline $\begin{array}{l}\text { Czech } \\
\text { Republic }\end{array}$ & $\begin{array}{l}\text { No definition of family and family members. } \\
\text { First Book of the Czech Civil Code expressly protects the family established by } \\
\text { marriage. }\end{array}$ \\
\hline Poland & No definition of family. \\
\hline Serbia & $\begin{array}{l}\text { The Serbian Family Act and other family laws do not contain a definition of } \\
\text { family. }\end{array}$ \\
\hline Slovakia & $\begin{array}{l}\text { Slovak Family Law was not uniformly regulated until } 1949 . \\
\text { Since 1950, family relations were not stipulated by the Civil Code but by a } \\
\text { separate law. } \\
\text { No definition of family. }\end{array}$ \\
\hline Slovenia & $\begin{array}{l}\text { Marriage is the main form of family. } \\
\text { The Slovenian Family Code provides a broad definition of family. } \\
\text { Family is an important social institution that enjoys special protection. } \\
\text { Family is a living community of the child, regardless of the child's age, with } \\
\text { both or one parent or with another adult, provided that the adult cares for the } \\
\text { child and has certain obligations and rights toward the child. } \\
\text { The child is a central element of the interpretation of family. }\end{array}$ \\
\hline Hungary & $\begin{array}{l}\text { Act on Family Protection: Originally stated that the basis of the family is exclusively } \\
\text { marriage between a man and a woman or a direct relationship, or guardianship. } \\
\text { In } 2012 \text { - the Decision of the Constitutional Court: this clause of the Act contradicts } \\
\text { the Basic Law } \rightarrow \\
\text { Before the Fourth Amendment of the Basic Law, the concept of family covered, } \\
\text { families based on marriage and in a sociological sense. } \\
\text { Fourth Amendment of the Basic Law: The basis of the family relationship is marriage } \\
\text { or the parent-child relationship. De facto partnerships are excluded. }\end{array}$ \\
\hline
\end{tabular}




\section{Legally acknowledged relationships}

\subsection{Legal protection and marriage}

In all the countries mentioned above, marriage is regulated and recognized on the same grounds. The Croatian Constitution protects marriage and states that "marriage is a union of a woman and a man." It stipulates that "Marriage and legal relationships in marriage, non-marital union and family shall be regulated by law". The Croatian Family Act allows marriage only between people of different sexes. The Czech Civil Code also defines marriage as a union between a man and a woman. However, a pending draft of a new law favors gender-neutral marriages. A second pending draft protects the traditional family model. According to Czech law, the main purposes of marriage are establishing a family, enabling the proper upbringing of children, and providing mutual support and help. Preserving solidarity between a married couple is of utmost importance. The Polish Constitution states that marriage is a relationship between a man and a woman. Thus, it does not acknowledge same-sex marriages. Homosexual couples are not allowed to marry, and cannot enter into registered partnerships, either. According to Serbian law, a man and woman can enter into marriage before a state body. The Serbian Constitution states that everyone has the right to decide freely on entering into or dissolving a marriage. Serbian law emphasizes the equality of men and women in the establishment and dissolution of marriages. In Slovakia, the Family Act explicitly defines marriage as a union between a man and a woman. According to Slovak family law, marriage is of a non-contractual nature. It is a union between a man and woman and aims at starting a family and raising children. The Family Act and the Constitution of the Slovak Republic protect marriage and families. Slovak family law does not recognize same-sex marriages and non-traditional forms of marriage and does not define or protect cohabitation. Although Slovenian family law offers a broad interpretation of the term "family," it defines marriage as a union between a man and a woman. Thus same-sex partners cannot marry in Slovenia. The basis for marriage is laid down in the Constitution, which provides that marriage shall be based on the equality of the spouses and solemnized before a competent State authority. The equality of spouses is reflected in the relationship between the spouses and with their common children. Two persons (man and woman) will only enjoy rights and obligations as spouses if their marriage is solemnized before a State authority: that is, a registrar and head of the administrative unit or a person authorized by the head, or a registrar and the mayor of the municipality in whose territory the marriage should be conducted, or a registrar alone. The Family Law Book under the Hungarian Civil Code declares that marriage shall be considered contracted if a man and a woman appear together before the registrar in person and declare their intention to marry. In Hungary, marriage is a bond between a man and a woman that results in personal and legal 
property effects. The Civil Code lays down the formalities for the conduct of marriage, and lists out the grounds for declaring a marriage invalid.

The table below summarizes the legal situation and protection of marriage

\begin{tabular}{|c|c|}
\hline Country & Protection of marriage \\
\hline Croatia & $\begin{array}{l}\text { The Constitution protects marriage. "Marriage is a union of a woman and } \\
\text { man." } \\
\text { Marriage and legal relationships in marriage, non-marital unions, and family } \\
\text { are regulated by law. } \\
\text { The Croatian Family Act allows marriage between people of different sexes. }\end{array}$ \\
\hline $\begin{array}{l}\text { Czech } \\
\text { Republic }\end{array}$ & $\begin{array}{l}\text { The Civil Code allows only marriage between a man and a woman. } \\
\text { A pending draft favors gender-neutral marriages. } \\
\text { A second pending draft protects the traditional family model. } \\
\text { The main purposes of marriage are establishing a family and maintaining } \\
\text { solidarity between the spouses. }\end{array}$ \\
\hline Poland & $\begin{array}{l}\text { The Constitution states that marriage is a relationship between a man and a } \\
\text { woman. } \\
\text { It does not acknowledge same-sex marriages. }\end{array}$ \\
\hline Serbia & $\begin{array}{l}\text { A man and a woman can enter into marriage before a state body. } \\
\text { Equality of man and woman during both the establishment and dissolution of } \\
\text { civil marriage is essential. }\end{array}$ \\
\hline Slovakia & $\begin{array}{l}\text { The Family Act defines marriage as the union between a man and a woman. } \\
\text { Marriage is of a non-contractual nature. }\end{array}$ \\
\hline Slovenia & Defines marriage as a union between a man and a woman. \\
\hline Hungary & $\begin{array}{l}\text { According to the Family Law Book under the Civil Code, a man and woman } \\
\text { can enter into marriage before the registrar. } \\
\text { Marriage has personal and property-related legal effects. } \\
\text { The Civil Code stipulates formalities and invalidity of marriage. }\end{array}$ \\
\hline
\end{tabular}

\subsection{Legal solutions for and the protection of same-sex partnerships}

The legal solutions for same-sex partnerships in Europe differ by country. In some countries, same-sex marriage is permitted. This is seen especially in Western European countries. Same-sex registered partnerships are also common, and are permitted, for example, in Hungary. Certain formalities and elements specific to registered partnerships are similar to those particular to marriage. However, there are some rights and possibilities that are not open to same-sex partners. The third form is a de facto civil partnership, or civil union that does not require adherence 
to any formalities. In some countries, such as Hungary, same-sex couples may enter into registered or de facto partnerships. There is no single, unified legal mechanism governing the protection of same-sex partnerships.

In Serbia, a draft act on same-sex unions is currently under discussion. It will regulate both registered and de facto same-sex unions if adopted. Like the Hungarian context, in the draft, same-sex partners have the same inheritance rights as do spouses. In Slovakia, the Family Act prohibits same-sex marriages and the registration of same-sex relationships before public administration bodies. Slovakian judicial practice has confirmed the basic principles Slovakian family law which prohibits same-sex marriages and registered partnerships Homosexuality has always been legal in Poland. In the Polish legal literature, homosexual persons living in long-term relationships are considered to live in partnerships. The legal status of same-sex unions is similar to that of cohabitants, that is, they can take advantage of social welfare benefits, enter into the rights of a deceased partner who was a tenant of a flat, and exercise the right to refuse to testify in proceedings. Unlike in Hungary, people in same-sex relationships in Poland are not entitled to inherit under the provisions of intestate succession. In Czechia there is a separate Act on Registered Partnerships, which is similar to the Hungarian model and serves as the main source of Czech Family Law. Some rights and duties of registered partners are similar to those of spouses, such as mutual maintenance duty based on "the same living standard." In case of death, the surviving partner has the same hereditary right as that of the surviving husband or wife in a marriage - this can also be found in Hungarian law. In Croatia, the Same-Sex Partnership Act names the same-sex partnership as a "life partnership." In 1998 the Republic of Croatia amended its family law on de facto same-sex unions. In 2014, it named two types of life partnerships: formal ones that can be listed in the registry of partnerships, and informal life ones by analogy to the legal regime of non-marital unions. Registered and life partnerships in Hungary and Croatia have some similarities. In both countries, if one of the partners in a life partnership has a child, the life partner is entitled to exercise parental responsibility. Registered partnership is a recognized form of same-sex unions. In Hungary, the Registered Partnership Act was adopted in 2009. In a registered partnership, two people of the same sex, both having reached the age of 18 years, personally enter into a registered partnership before the registrar. There are many similarities between marriages and registered partnerships, for example partners in both cases can inherit under the provisions of intestate succession but cannot marry and adopt children jointly. In Slovenia, the Civil Unions Act was adopted in 2016, which granted almost the same rights to the same-sex partners in a civil union as those granted to spouses in a marriage. Slovenian law does not grant same-sex partners the right to marry and adopt children. 
The table below presents details on the legal protection of same-sex partnerships

\begin{tabular}{|c|c|}
\hline Country & Protection of same-sex partnerships \\
\hline Serbia & $\begin{array}{l}\text { The draft act on same-sex unions is currently under discussion. } \\
\text { Registered same-sex unions and de facto same-sex unions are permitted. } \\
\text { Same-sex partners have the same inheritance rights as do married spouses. }\end{array}$ \\
\hline Slovakia & $\begin{array}{l}\text { The Family Act does not allow same-sex marriages. } \\
\text { It does not allow the registration of same-sex relationships. }\end{array}$ \\
\hline $\begin{array}{c}\text { Czech } \\
\text { Republic }\end{array}$ & $\begin{array}{l}\text { Interesting legal situation (two separate drafts). } \\
\text { Separate Act governing Registered Partnerships. } \\
\text { Some rights and duties of registered partners are similar to those of married } \\
\text { spouses. } \\
\text { Same-sex persons are not allowed to adopt minor children jointly or become } \\
\text { joint foster parents of minors. }\end{array}$ \\
\hline Poland & $\begin{array}{l}\text { Homosexuality has always been legal. } \\
\text { Homosexual persons living in long-term relationships are qualified. } \\
\text { Legal status is similar to that of cohabitants. } \\
\text { They are not entitled to inherit under the provisions of intestate succession. } \\
\text { They cannot adopt children. }\end{array}$ \\
\hline Croatia & $\begin{array}{l}\text { The Same-Sex Partnership Act considers same-sex partnerships "life } \\
\text { partnerships." } \\
\text { In 1998, Croatia amended its family law to address de facto same-sex unions. } \\
\text { It distinguished between two types of life partnerships: } \\
\text { Life partnership (registry). } \\
\text { Informal life partnership (similar to non-marital union). }\end{array}$ \\
\hline Slovenia & $\begin{array}{l}\text { The Civil Unions Act was adopted in } 2016 \rightarrow \text { It granted almost the same } \\
\text { rights to same-sex partners in a civil union as it does to married spouses. } \\
\text { Same-sex partners cannot marry and jointly adopt children. }\end{array}$ \\
\hline Hungary & $\begin{array}{l}\text { Registered partnerships. } \\
\text { The Registered Partnership Act was adopted in } 2009 . \\
\text { Two same sex persons who reached the age of } 18 \text { years. } \\
\text { Similarities to marriage (e.g., inheritance rules). } \\
\text { Differences: Same-sex partners cannot marry and jointly adopt children. }\end{array}$ \\
\hline
\end{tabular}

\subsection{Legal issues and protection of de facto partners}

According to Hungarian family law, de facto partners live together outside of wedlock or in a registered partnership in an emotional and financial community in the same household. A similar basis for de facto partnerships is found in other Central European countries. Slovakian family law does not recognize non-traditional 
forms of marriage, and consequently, does not protect cohabitation. The Czech Civil Code protects families established by marriage. Thus, there are no rules in the Czech Civil Code that can establish the mutual rights and duties between cohabitees. The Czech country report emphasizes that property contracts between the cohabitees are not common in the practice. This causes some practical problems as there is a weaker party in such a relationship. On the lines of the Hungarian rules, there is no discrimination of children born out of wedlock, the rights and duties of the parents of any child are equal. In Croatia, informal non-marital unions were introduced for the first time within the scope of family law in 1978. In 1990, non-marital unions became a constitutional category in Croatia. The Croatian family law defines nonmarital union as a "union of an unmarried woman and an unmarried man lasting for at least three years or shorter if the common child had been born therein or has been continued by entering into the marriage."

Serbian law considers non-marital cohabitation a de facto relationship. It is not possible to register non-marital cohabitation, which means that there may be difficulties in proving the existence of a non-marital cohabitation before a court of law. In Serbia the community property regime (as in marriage) is the statutory regime in a non-marital cohabitation. The community property is the property that spouses acquire through work if they live together. Non-marital cohabitation is defined as the sustained cohabitation of a man and woman between whom there are no marital impediments. In the Polish legal system, cohabitation refers to a man and a woman living together in a stable relationship. It is realized in economic, spiritual, and sexual spheres. As it is an informal relationship, it need not be registered. Cohabitation does not create a formal ground for the use of a partner's apartment and property. Matrimonial laws do not apply to cohabitants. According to Polish law, cohabitants have joint custody over their children, and their parental rights are mainly the same as those of married parents. However, cohabitants cannot adopt children jointly.

For a long time, Hungarian family law considered marriage the basis for the formation of a family. However, changes in society made it necessary to offer legal protection for other forms of social cohabitation as well. Cohabitation was a social trend that Hungarian legislation could no longer ignore. In Hungary, the legal regulation of de facto partnerships is really special. De facto partners can be same-sex or heterosexual persons. Hungarian law offers a dual regulation regime for de facto partnerships, because the relationship can have family law effects, and this relationship is contractual in nature. The definition of such relationship and their property related rules are incorporated in the Obligation Law Book of the Civil Code. De facto partnerships have family law effects only if the partnership has existed for at least one year, and the partners have a common child from their relationship. If same-sex partners live in a de facto cohabitation, then this relationship has no family law effect, because these partners cannot have a common child from this relationship. Cohabitants enjoy strong protection in Slovenia, where they enjoy the same rights as spouses in both family and legal matters. Following the Constitution, the new Family Code defines cohabitation as: "An extramarital union is a long-term life community 
between a man and a woman who have not been married, and there are no reasons why the marriage between them could be invalid. Such a community has the same legal consequences under this Code as if they had been married; in other areas of law, however, such a community has legal consequences if the law so provides."

The table below summarizes the legal protection of de facto partnerships

\begin{tabular}{|c|c|}
\hline Country & Protection of de facto partnerships \\
\hline Croatia & $\begin{array}{l}\text { Informal non-marital unions were introduced into the family law system in } \\
1978 . \\
\text { In 1990, non-marital unions became a constitutional category in Croatia. } \\
\text { The union between an unmarried woman and unmarried man lasting for at } \\
\text { least three years or below if the common child had been born therein or has } \\
\text { been continued by entering into the marriage. }\end{array}$ \\
\hline Serbia & $\begin{array}{l}\text { De facto relationships. } \\
\text { It is not possible to register non-marital cohabitation as doing so causes dif- } \\
\text { ficulties in court practice. } \\
\text { The statutory regime is the community property regime. }\end{array}$ \\
\hline Poland & $\begin{array}{l}\text { A man and a woman living together in a stable relationship. } \\
\text { The relationship is realized in economic, spiritual, and sexual spheres. } \\
\text { Cohabitants have joint custody over their children and parental rights are the } \\
\text { same as those of married parents. } \\
\text { The couple cannot adopt children jointly. }\end{array}$ \\
\hline Slovenia & $\begin{array}{l}\text { Strong protection mechanism. } \\
\text { They enjoy the same rights as those of married spouses. }\end{array}$ \\
\hline Slovakia & $\begin{array}{l}\text { The law does not recognize non-traditional forms of marriage. } \\
\text { It does not protect cohabitation. }\end{array}$ \\
\hline $\begin{array}{l}\text { Czech } \\
\text { Republic }\end{array}$ & $\begin{array}{l}\text { The Civil Code expressly protects families established by marriage. } \\
\text { Informal relationships enjoy protection. } \\
\text { There are no rules under the Czech Civil Code that would establish mutual } \\
\text { rights and duties. } \\
\text { There are no property contracts between the cohabitees. } \\
\text { There is no discrimination of children born out of wedlock. }\end{array}$ \\
\hline Hungary & $\begin{array}{l}\text { De facto partners can be same-sex and heterosexual persons as well. } \\
\text { Dualistic approach: } \\
\text { A relationship can have family law effects (at least one year and one child) } \\
\text { A kind of contractual relationship (definition and property rules). }\end{array}$ \\
\hline
\end{tabular}




\subsection{Legal status of children born in and out of wedlock}

Children enjoy the same legal status regardless of whether they are born in or out of wedlock in all Central European countries. Some countries' domestic regulations expressly state this. The Slovenian Constitution prohibits discrimination on the grounds of birth and provides that children born out of wedlock shall have the same rights as those born in wedlock. According to the Constitution and Family Act of Serbia a child born out of wedlock has the same rights as a child born in marriage. The status of a child born out of wedlock does not depend on whether the child was born in a non-marital cohabitation or that the non-marital cohabitation never existed. The presumptions of paternity in the Hungarian legal system are uniform, which means that they have the same legal consequences regardless of whether the child was born in or out of wedlock. The Czech Civil Code establishes that kinship is based on blood ties or originates from adoption, which is constructed as a status change.

The table below summarizes the legal status of children born in and out of wedlock

\begin{tabular}{|c|l|}
\hline Country & \multicolumn{1}{|c|}{ Legal status of children born in and out of wedlock } \\
\hline Slovenia & The Constitution prohibits discrimination on the grounds of birth. \\
\hline Serbia & $\begin{array}{l}\text { A child born in wedlock has the same rights as a child born out of wedlock, } \\
\text { under the Constitution. }\end{array}$ \\
\hline Hungary & No difference in the child's legal status (Civil Code). \\
\hline $\begin{array}{c}\text { Czech } \\
\text { Republic }\end{array}$ & Kinship is based on blood ties and adoption (Civil Code). \\
\hline
\end{tabular}

\section{Descendant family relationship}

Descendant family relationship is one of the most important components of family law, as these rules on the one hand determine the origin of the child and on the other hand constitute the family relationship with the rights and obligations of the parties. In this part we will examine the issues of father status, mother status and adoption. 


\subsection{Issues concerning the father's status: Presumptions of paternity}

The presumptions of paternity and judicial decisions serve as common grounds in Central European countries, with some domestic specialties. The importance of the family status of the child is lightning back in the interest of a normal family life. The orderliness of the family status of the child provides a basis for the child to live in a legally recognized family. This is legally complete if both parental statuses are occupied in the child-parent relationship. Regarding the topic there are some general features which are the same in the countries' legal systems. On the one hand it can be stated that fathers' status can mainly be based on four ways in the Central European countries, namely the marriage bond, recognition (acknowledgment) of the man, the judgment of the court and, in some countries, biomedical assistance procedure.

Consequently, we highlight only those specialties where we can find discrepancies. On the other hand, it also can be ascertained as a second general feature, that the first three varieties prevail in some legal form while the fourth, the biomedical assistance procedure or with other words human reproduction procedure is known and regulated only in some countries. Based on these, we will describe the similarities and differences below.

\subsubsection{Marriage bond}

The first of the paternity presumptions is the marriage bond, which was put in place in all the examined countries. The most important component of the marriage bond is strengthening the position of the mother's husband, because he is considered the father of the child(ren). Among the legal systems, we can find some samples for that the father's status is based on that whether the child born during the marriage or after the termination of marriage for a period of time. Here, there is a difference based on how the marriage was terminated - that is, by divorce (dissolution) or death. If the marriage was terminated by death or dissolution, but the child was born within 300 days after such termination, the mother's husband shall be considered the father. If marriage was terminated by dissolution and over 300 days have passed since such dissolution, the ex-husband will not be the father of the child, but the new husband, if any. This rule is in place in Croatia, Serbia, the Czech Republic, and Slovenia. In contrast, in Hungary and Slovakia the main point of contention is not the date of termination and birth. Rather, the calculation goes backward, wherein, if the mother lived in a marriage at the presumed date of conception - which is calculated backward from the date of birth - the husband at that time shall be considered the father.

Based on these differences, we list out the following observations. In Serbia the husband of the child's mother shall be considered the father if the child was born within 300 days after the termination of marriage. In the Serbian legal system, this rule can apply only if the marriage was terminated by the death of the husband and if the mother did not conclude another marriage in this period. Serbian law also adds 
that the new husband of the child's mother shall be considered the father of a child born during that marriage, regardless of how short a time may have elapsed between the termination of the former marriage and the establishment of the new one. According to Slovenian family law, the legal presumption of paternity is extended to 300 days after the dissolution of the marriage only if the dissolution is because of the mother's husband's death, like in the Serbian model. Children born out of wedlock or after more than 300 days after the dissolution of the marriage are not covered by the legal presumption of paternity. In such cases, paternity will have to be established either by acknowledgment or a court decision. The abovementioned principle is also applicable in the Czech Republic. If a child is born in wedlock or within 300 days after the termination of the marriage, the mother's husband shall be the father. In the Polish system, it is presumed that the husband of the woman who gives birth to a child is the father of the child.

In Hungary, a man shall be considered the father of the child with whom the mother lived in marriage from the alleged time of conception until the birth of the child, or at least during a part of this period. The presumed time of conception refers to the period between the $182^{\text {nd }}$ and $300^{\text {th }}$ days since the date of the child's birth, including both dates. If the child is claimed to have been born before or after the presumed time of conception, it may be verified by evidence. For the presumption to apply, it does not matter whether the spouses actually lived together or whether the mother had sexual contact with her husband alone. Therefore, the husband of the mother must be considered the father of the child even if the mother is already living with another man - without the termination of her previous marriage - and the child was conceived through the mother's sexual contact with that other man. We can find a similar legal solution in Slovakia as well, where the expected conception date is the day between the $180^{\text {th }}$ and $300^{\text {th }}$ days before birth.

\subsubsection{Recognition of the man}

In most countries, the recognition (acknowledgment) of the man is considered the second presumption that can establish paternity. It is quite different in the Hungarian system, where recognition is the third in the list of paternity presumptions. In all the analyzed countries, if the child was born out of wedlock, the father's status can be determined by recognition. There are a few different rules concerning the need for the consent of the mother and/or child. The consent of a mother is vital in the countries examined because it confirms the veracity of the recognition. If a man acknowledges his paternity and the mother consents to it, the man shall be considered the father, regardless of biological fact. In some countries like Croatia, Serbia, and Hungary, there is a need for consent in special cases, as well. Some additional specialties are listed below.

In Croatia, if the mother is not alive or her residence is unknown, the consent of the child's guardian is necessary along with prior approval from the social welfare center. This is also the case in Serbia, where if neither the mother nor the child can 
give consent, the child's guardian with prior consent of the guardianship authority can provide it. In Serbia, a man can recognize a child as his own until the child turns 16 years of age. In Slovakian law, recognition is provided by a joint statement by both parents, rather than a unilateral acknowledgment. Thus, it is known as a "joint statement of recognition by parents" and not a paternal statement of recognition. In Hungary, there is an additional rule that once a statement or document is signed, the recognition of paternity may not be withdrawn. The Slovenian regulation emphasizes that the recognition of paternity is a strictly personal unilateral declaration of will that is made in the prescribed form (i.e., at a social work center, before a registrar, in a public deed, or in a last will).

\subsubsection{Judgment of the court}

In the Polish, Serbian, Slovak, Czech, and Hungarian systems, courts can establish paternal status. This legal solution prevails when the marriage bond or recognition cannot apply. It effectively applies if the child was born out of wedlock. The court's decision is based on the occurrence of sexual intercourse in the critical period, which means that a man shall be considered the unmarried woman's child, if he had a sexual relationship with the woman within a given period of time. This period varies by country. For example, in the Czech Republic, it is 160 to 300 days before birth, in Hungary, it is the period between the $182^{\text {nd }}$ and $300^{\text {th }}$ days before the date of the child's birth, including both deadlines. In Slovakia, the period between 180 and 300 days is considered decisive. In connection with the paternal status based on judicial decisions, mostly the same features can be ascertained, but some specialties can be highlighted. Slovenian law emphasizes that children born out of wedlock or not born within 300 days of the dissolution of marriage owing to the father's death are not subject to the legal presumption of paternity based on marriage. In such cases, paternity shall be established by recognition or court decision.

In the Serbian and Hungarian systems, paternal status determined by court cannot be questioned. The Hungarian legal system indicates that the judicial determination of paternity is not possible in the case of a donor donating a gamete or embryo if the mother became pregnant through an assisted reproductive procedure. The presumption of paternity is established by a court when it is necessary to determine the paternity of a man who has procreated, but does not wish to exercise paternity. According to Hungarian law, two elements shall be proven during the judicial procedure: one, that the man has engaged in sexual intercourse with the mother at the time of conception and upon careful consideration of all circumstances (based on physiological tests), there are reasonable grounds to consider that the child was conceived as a result of such sexual contact. Slovakian law has similar features as the Family Act emphasizes that a man shall be considered the father if he has had sexual intercourse with the mother of the child at the time of conception, unless other circumstances preclude his paternity. 


\subsubsection{Biomedical assistance procedures}

Biomedical assistance procedures can be considered to pave the way for a paternal presumption. However, it is not so in all the Central European countries analyzed. The Serbian, Slovenian, and Hungarian systems permit it. In Serbia and Hungary, the mother's husband shall be considered the father of the child if the child was conceived through biomedical assistance, provided that the man granted written consent to the procedure. Serbian law emphasizes that the paternity of a man considered to be the child's father because of biomedical assistance cannot be contested. However, the man himself has the right to contest paternity if the child was not conceived through a biomedical procedure. Under Slovenian law, biomedical procedures are governed by the Infertility Act. If a child is conceived by a biomedical procedure, the legal presumption of paternity extends to the extramarital partner and the mother's husband. The paternity of a child conceived by biomedical means may not be contested, except if the child was not conceived by an assisted reproduction procedure. In Hungary, paternity based on human reproduction procedure (assisted reproduction procedure) can be contested within strict regulations and conditions alone. It has to be mentioned also, that this special procedure is the second one in the line of paternity presumptions in the Hungarian family law and it is also really important that it can establish paternal status only in the case of de facto partners, because if a married couple takes part in biomedical assistance procedure, the paternal status is based on the marriage bond. In the Hungarian system, the special procedure can be carried out by people living in a marriage bond or by heterosexual couples living in a de facto cohabitation, if it is unlikely for a child to be conceived naturally because of the infertility of either party. However, in the case of a de facto cohabitation, reproduction procedures may be carried out only if none of the de facto cohabitants has a marital relationship.

The following table summarizes the paternity presumptions

\begin{tabular}{|c|l|}
\hline Country & \multicolumn{1}{|c|}{ Paternity presumptions } \\
\hline Croatia & $\begin{array}{l}\text { Fatherhood can be established by: } \\
\text { marriage bond, or } \\
\text { recognition (acknowledgment), or } \\
\text { judgment of the court. }\end{array}$ \\
\hline Serbia & $\begin{array}{l}\text { Fatherhood can be established by: } \\
\text { marriage bond, or } \\
\text { recognition (acknowledgment), or } \\
\text { judgment of the court, or } \\
\text { biomedical assistance procedure - if the man has granted written consent to such a } \\
\text { procedure. }\end{array}$ \\
\hline
\end{tabular}




\begin{tabular}{|c|l|}
\hline Country & \multicolumn{1}{|c|}{ Paternity presumptions } \\
\hline Slovenia & $\begin{array}{l}\text { Fatherhood can be established by: } \\
\text { marriage bond, or } \\
\text { recognition (acknowledgment), or } \\
\text { judgment of the court, or } \\
\text { biomedical assistance procedure - governed by a separate Act. }\end{array}$ \\
\hline $\begin{array}{c}\text { Czech } \\
\text { Republic }\end{array}$ & $\begin{array}{l}\text { Fatherhood can be established by: } \\
\text { marriage bond, or } \\
\text { recognition (acknowledgment), or } \\
\text { judgment of the court (on the basis of the conduct of sexual intercourse within the } \\
\text { critical period of time). }\end{array}$ \\
\hline Hungary & $\begin{array}{l}\text { Fatherhood can be established by: } \\
\text { marriage bond, or } \\
\text { biomedical procedure in the case of de facto partners, or } \\
\text { recognition (acknowledgment if the parties are not married), or } \\
\text { judgment of the court. }\end{array}$ \\
\hline Plovakia & $\begin{array}{l}\text { Fatherhood can be established by: } \\
\text { marriage bond, or } \\
\text { recognition (acknowledgment), or } \\
\text { judgment of the court. } \\
\text { marriage bond, or } \\
\text { recognition (acknowledgment in the form of a joint statement), or } \\
\text { judgment of the court. }\end{array}$ \\
\hline
\end{tabular}

\subsection{The mother's status}

For a long time, the mother status was the most obvious point under family law, because according to the old Roman law principle, the child's mother is the one who gave birth to the child. Nowadays, while it is easier to determine than the father's status, there are additional questions that must be examined in light of the mother's status, namely surrogacy and nursing pregnancy. Maternal status is important for every child. According to international obligations, it is necessary to register a child soon after birth and to acknowledge their mother in order to make the parental status clear.

\subsubsection{The fact of childbirth}

The Central European countries examined manage the mother's status based on the aforementioned old Roman law principle. This principle can apply in connection 
with surrogate motherhood and nursing pregnancy as well. None of the Central European countries examined permit surrogate motherhood and nursing pregnancy. This is emphasized in Slovakian law as a non-rebuttable presumption of maternity. The Slovak Family Act stipulates the invalidity of any contracts and agreements that run counter to this principle.

Croatian law adds a few administrative rules that indicate that children born in a health institution are reported to the civil registrar by the health institution and the women who give birth to such children are registered as their mothers. If childbirth happens outside a health institution, it is reported by the child's father or the person in whose household the child was born. In such cases, the person reporting the child's birth is obliged to provide the civil registrar with medical documentation on the birth or the proof of motherhood. Under the Czech Civil Code, this is mandatory. The basis of the mother's status is the fact of birth in the Czech system as well, which includes assisted reproduction. The legal mother of a child is the one who gives birth to the child, irrespective of who the donor of the egg may be. Legal motherhood is identical to biological motherhood. In the case of egg donation, genetic motherhood becomes irrelevant. The Czech system permits hidden childbirth, where a woman with permanent residency in the territory of the Czech Republic has a right to have her identity hidden in connection with birth if she does not have a husband who has a presumption of fatherhood. There are also baby-boxes for unregistered unwanted children, where mothers can leave their new-born babies. Surrogate motherhood is not regulated under Czech law. Polish law also emphasizes the Roman law-based principle. Like the other Central European countries, surrogate motherhood and concluding such contracts have always been invalid in Poland. Under the Slovenian Family Act, a woman who gives birth to a child is considered the child's mother. This is considered irrebuttable. An average of six couples in Slovenia face infertility and related problems, which lead to legal novums as well, such as egg donation (ovum) which is allowed in Slovenia. If a mother has consented to an assisted reproduction procedure, her maternity cannot be challenged. If the child was conceived with the help of a donor egg, her maternity cannot be contested. However, embryo donation and surrogacy are not allowed in Slovenia. Serbian Law emphasizes this as well and stipulates that if a child is conceived through biomedical assistance with a donated ovum, the maternity of the woman who donated the ovum may not be established. Under Serbian law, the mother is the one who gives birth to the child and it also prohibits surrogacy.

A similar situation prevails in Hungary as well, where the law treats motherhood as a fact and not as a presumption. The Civil Code chooses between biological and genetic mothers in keeping with international practice and considers the woman who gives birth of a child as the mother. Although the Civil Code does not regulate the recognition of maternity, it may be appropriate in a case where there is a vacancy in the maternal status if the mother demands the child within six weeks and can prove beyond doubt that she is the real, biological mother of the child. A woman who has asked another woman to carry an embryo derived from her ovum cannot be considered a mother. In Hungary, surrogacy and nurse pregnancy are not allowed. 


\subsubsection{Judicial decisions}

Courts can help address the mother's status, especially if there is a doubt about who the child's mother is. This is managed in a similar manner in the countries analyzed. The Slovakian Family Act states that if there is any doubt about a child's mother's identity, motherhood shall be determined by the court based on the facts ascertained around the birth of the child. In Croatia, motherhood can be determined by a judicial decision if the box containing data on the child's mother has been left empty. An action may be filed by the child until they turn 25 years of age, or the woman who claims to be the child's mother, or a social welfare center before the child turns 18. In court proceedings, evidence of the child's biological mother's identity should always be provided using DNA, although the court is not bound by such evidence.

According to Serbian law, maternity can be established by a court decision in an exceptional instance where a woman who gave birth to a child was not registered in the Birth Register as the child's mother. The child and the woman claiming to be the child's mother have the right to establish maternity. A child may initiate action to establish maternity at any time, and a woman claiming to be the child's mother may initiate an action to establish her maternity within a year of learning that she gave birth to that child (but no later than 10 years from such birth). Maternity can be contested, as well. This procedure is necessary in cases where wrong data regarding the child's mother have been entered into the register. A similar solution prevails in Hungary as well, wherein if the identity of the mother of a child is in dispute or cannot be established, this question can only be clarified in a maternity lawsuit in accordance with the Civil Code. The aim of the claim is to give the mother's status to the designated person. This request can be issued if the maternity status is empty and the plaintiff seeks to establish that the person shown in the registry of births as the mother is not the one who gave birth to the child and that the mother is the designated person.

The following table outlines the issues pertaining to the mother's status

\begin{tabular}{|l|l|}
\hline Country & \multicolumn{1}{c|}{ Mother's status } \\
\hline Slovakia & $\begin{array}{l}\text { The mother of the child is the woman who gives birth to the child } \\
\text { Court proceedings - if there is any doubt around the identity of the child's } \\
\text { mother } \\
\text { Surrogate motherhood and nursing pregnancy are not allowed }\end{array}$ \\
\hline Croatia & $\begin{array}{l}\text { The mother of the child is the one who gives birth to the child } \\
\text { Court proceedings - if the box containing data on the child's mother has been } \\
\text { left empty } \\
\text { Surrogate motherhood and nursing pregnancy are not allowed }\end{array}$ \\
\hline
\end{tabular}




\begin{tabular}{|c|l|}
\hline Country & \multicolumn{1}{c|}{ Mother's status } \\
\hline Serbia & $\begin{array}{l}\text { The mother of the child is the one who gives birth to the child } \\
\text { Court decisions - if she was not registered in the Birth Register as the child's } \\
\text { mother } \\
\text { Surrogate motherhood and nursing pregnancy are not allowed }\end{array}$ \\
\hline $\begin{array}{c}\text { Czech } \\
\text { Republic }\end{array}$ & $\begin{array}{l}\text { The mother of the child is the one who gives birth to the child } \\
\text { Surrogate motherhood and nursing pregnancy are neither allowed nor prohibited }\end{array}$ \\
\hline Hungary & $\begin{array}{l}\text { The mother of the child is the one who gives birth to the child } \\
\text { Court proceedings - if there is any doubt about the child's mother's identity } \\
\text { Surrogate motherhood and nursing pregnancy are not allowed }\end{array}$ \\
\hline Slovenia & $\begin{array}{l}\text { The mother of the child is the one who gives birth to the child } \\
\text { Surrogate motherhood and nursing pregnancy are not allowed }\end{array}$ \\
\hline Poland & $\begin{array}{l}\text { The mother of the child is the one who gave birth to the child } \\
\text { Surrogate motherhood and nursing pregnancy are not allowed }\end{array}$ \\
\hline
\end{tabular}

\subsection{Regulations on adoption}

\subsubsection{General features of adoption}

The main purpose of adoption is the same in all the Central European countries, namely to ensure that minors can grow up in families, if their biological parents are unable to raise them. All the examined countries regulate adoption in a similar manner. Most country reports have emphasized that adoption is the best option where a permanent replacement of the absent parents or their care as part of parental care is necessary. Adoption is the best alternative for children who cannot be cared for by their parents. It aims to provide a stable, secure, and caring environment for the child in which the child can grow up and develop harmoniously. The main consequence of adoption is similar in all the countries analyzed in that it will change the legal status of the child wherein the adoptive parents will be the child's parents and will exercise parental control over him/her. We present the requirements of adoption in the following section. This part covers the question of whether a single person, or de facto partners, or same-sex partners can adopt a child.

\subsubsection{The requirements of adoption vis-à-vis the adoptive parent}

Most countries have some general requirements and prescribe some age-related regulations as well for adoptive parents to follow. We highlight the issues and opportunities around adoption for single people, and de facto and same-sex partners.

First, the general requirements and age-related regulations are presented. The Croatian system emphasizes that adoption cannot be cancelled and that adoptive 
parents can be admitted as parents, and that adoption creates legal consequences for the relatives of the adoptive parents with respect to the child. The Slovenian legal system emphasizes that during adoption, a child's ethnic, religious, cultural, and linguistic background shall be considered to ensure the continuity of the child's upbringing in a family environment. There are additional regulations for biological parents. Parents who have consented to the adoption of their child after birth but before the child is eight weeks old must reconfirm after eight weeks. Otherwise, the consent has no legal effect. Adoption can take place only after six months have lapsed since the consent was given, which still gives parents the chance to withdraw their consent. Polish law emphasizes that the adoptive parent shall be suitably older than the adopted child. This is ascertained at the adoption center, which issues a certificate of completion of relevant training and an opinion on whether the candidate is qualified to adopt a child. Czech law emphasizes obligatory pre-adoption care, which cannot be less than six months. The rule says that after receiving the parents' consent to adoption and placing the child in the pre-adoption care of the prospective adopters, the exercise of parental responsibility of the child's parents is suspended and the court must appoint a guardian for the adoptee. The Hungarian Civil Code stipulates that any person whose parental supervision has been terminated by a court order or who has been excluded from public affairs, and whose child is under foster care may not adopt a child. In Hungary, adoption is authorized by the guardian authority if the legal requirements are met and if it is deemed to be in the child's best interest. The Civil Code also lays down concrete regulations regarding the age of the adoptive parent, who must be at least 25 years of age with legal capacity, and older than the child by at least 16 to 45 years. It also indicates that one shall be considered suitable to adopt a child based on his/her personality and other circumstances. In the case of a child aged over three years, adoption may be authorized if the age difference between the adoptive parent and the child is not more than 50 years. In the case of adoption by a relative or spouse, the age difference requirement does not apply. In the case of adoption as a common child, these requirements shall be satisfied by either of the adoptive parents. If the adoptees are siblings, the age of the older child shall be taken into consideration. According to the Serbian legal system, the following people cannot adopt: a person who is fully or partially deprived of parental rights or legal capacity, a person suffering from an illness that may have detrimental effects on the adoptee, and a person convicted of a crime belonging to the group of crimes against marriage and family, sexual freedom, and life and body. In Serbia, too, there are concrete regulations on age differences, on the lines of the Hungarian model. The difference in age between the adopter and adoptee must be between 18 and 45 years.

Another interesting issue is whether or not a single person or person living in a de facto cohabitation or same-sex partnership can adopt, and if they can, under what conditions. In Croatia, a wide circle of individuals can adopt. According to the rules, married and non-married spouses may adopt jointly, a person who is married or has entered into a non-marital union may adopt with the consent of the married 
or non-married spouse, and a person who is not married or has not entered into a non-marital union can adopt. Nothing prevents a person who is single and/or homosexual from adopting a child. Nothing prevents a person who was the life partner of a child's parent from adopting a child after the termination of such life partnership. Slovenian family law prescribes that a child may be adopted jointly by spouses or extramarital partners. Under the law, both partnerships can only be established by different-sex partners. In Slovenia, same-sex partners cannot adopt a child together. In addition to joint adoption, the law also allows single adoption. We can talk about the so-called stepparent adoption if a spouse or extramarital partner adopts a child of his/her spouse or extramarital partner. It is also be carried out exceptionally for a child if it is impossible to obtain adoptive parents who are spouses or extramarital partners and if this would meet the child's best interests. In such a case, a child can also be adopted by one person. In the case of single adoption, the partner from a civil union or de facto civil union can adopt the partner's child. Cohabitants and same-sex partners cannot adopt a child jointly in Poland, as joint adoption is open only for spouses. In Polish legal practice, it is impossible to adopt a partner's child, as this would lead to the termination of the legal relationship between the child and parent. A married couple may adopt a child. It is possible for a single person to adopt a child. In the Czech Republic, only married couples can adopt a child jointly. The law also allows adoption by one of the spouses and in exceptional circumstances, by another person. The Czech system allows re-adoption, or the adoption of an already adopted child. In Hungary, a child may only be adopted by married couples, except where the child is adopted by a relative or by the parent's spouse. Registered partners and de facto cohabitants cannot adopt. The joint adoption of a child by same-sex partners is not allowed. A single person can adopt a child only with a license from a minister in a justified case. In Serbia, spouses and cohabitees can adopt together. The minister responsible for family protection may grant permission to a person who lives alone to adopt, if it can be justified by special reasons. In Slovakia, only married spouses can adopt a child jointly.

\subsubsection{Rules concerning the adopted child}

In most countries, only minors can be adopted. This aligns with the purpose of adoption, that is, a child should grow up in a family. However, there is an exception to this. The Czech Republic permits the adoption of an adult. Adoption creates the same relationship between the adoptive parents and the child as that between natural parents and their children. Slovenian law prohibits prenatal adoption. In Poland, the general requirement on the side of the child is that (s)he can be adopted if the parents fail to exercise parental authority because they are dead, or unknown, or have consented to the adoption of their child, or, if the parents' custody rights have been removed altogether. Polish law allows adult adoptees to know their biological origins. The adoption of minor children requires parental consent in the Czech system. The child's mother can consent to the adoption after the expiry of 
six weeks from the birth of child. The child's father can consent at any time after the child's birth. Parents aged under 16 years cannot consent to adoption. A child aged over 12 years must consent to his or her adoption and this consent can be revoked. Adoptive parents have a duty to inform the adoptee about adoption as soon as appropriate, but no later than when the adoptee starts compulsory schooling. In Hungary, it is an important requirement that a minor of limited legal capacity aged over 14 years may be adopted only with his/her consent. A minor under the age of 14 years shall be heard and their opinion shall be taken into consideration wherever appropriate. In Serbia, a minor can be adopted after (s)he aged the third month. In the case of a child who has reached 10 years of age and is capable of reasoning shall gives his/her consent to the adoption.

The table below shows the legal regulations concerning adoption

\begin{tabular}{|c|c|}
\hline Country & Adoption \\
\hline Croatia & $\begin{array}{l}\text { Who can adopt: } \\
\text { marital spouses jointly } \\
\text { non-marital spouses jointly } \\
\text { single adoption }\end{array}$ \\
\hline Slovenia & $\begin{array}{l}\text { Who can adopt: } \\
\text { marital spouses jointly } \\
\text { single adoption }\end{array}$ \\
\hline Poland & $\begin{array}{l}\text { Who can adopt: } \\
\text { marital spouses jointly } \\
\text { single adoption }\end{array}$ \\
\hline $\begin{array}{c}\text { Czech } \\
\text { Republic }\end{array}$ & $\begin{array}{l}\text { Who can adopt: } \\
\text { marital spouses jointly } \\
\text { single adoption }\end{array}$ \\
\hline Hungary & $\begin{array}{l}\text { Who can adopt: } \\
\text { marital spouses jointly } \\
\text { single adoption - with the license of the appropriate minister in a justified } \\
\text { case. }\end{array}$ \\
\hline Serbia & $\begin{array}{l}\text { Who can adopt: } \\
\text { marital spouses jointly } \\
\text { single adoption - with the license of the appropriate minister in a justified } \\
\text { case. }\end{array}$ \\
\hline Slovakia & $\begin{array}{l}\text { Who can adopt: } \\
\text { marital spouses jointly }\end{array}$ \\
\hline
\end{tabular}




\section{Parental responsibility}

Minors are placed under parental responsibility or in parental custody. First, we outline the scope of parental responsibility and provide an overview of the rights of single parents and parents who live together.

\subsection{The scope of parental responsibility}

Parental responsibility is a significant component of the parent-child relationship as it determines the extent of the rights and duties that are vested and oblige the parents toward each other and their child(ren). The central components of parental responsibility are similar across all Central European countries. These components are:

- care and protection of the child,

- education of the child,

- legal representation of the child,

- management of the child's assets, and

- maintenance of the child.

Some countries include other components of parental custody. For example, the determination of the home and residence of a child can be found in Croatian, Czech, and Hungarian laws as well. In the Hungarian system, there are a few more elements, such as naming a child, the right to nominate a guardian, and the right to be excluded from guardianship. Act LXXIX of 2021, which was enacted in June 2021, also contains several child protection rules in addition to stricter action against pedophiles. By amending the Child Protection Act, it was declared that the state protects the right of children to their self-identity according to their birth gender in the child protection system. Pornography and content that depicts sexuality self-centered, or promotes deviation from the gender identity ascribed at birth, gender reassignment, and homosexuality is prohibited if it involves anyone aged under 18 years. It is also prohibited to make available to anyone aged under 18 years any advertisement that depicts sexuality self-centered, or that promotes deviation from the gender identity ascribed at birth, gender reassignment, and homosexuality. With the amendment of the National Public Education Act, school sessions on sexual culture, life, orientation, and development should not be aimed at promoting the deviation from one's gender identity assigned at birth, gender reassignment, and homosexuality. A person or organization other than the employee of an educational institution in a teaching position, a school health service specialist from an established institution, and a state body with a cooperation agreement concluded with the institution are entitled to conduct a school session on sexual development, the harmful effects of drug use, the dangers of the Internet, and other areas of improvement under the ambit of physical and mental health only within the limits set by law. Serbian family law emphasizes that parents have the right and duty to take care of their children personally, which 
implies that they cannot carry out humiliating actions and punishments that insult their children's dignity. They also have the duty to protect their children from such actions by other people. Parents cannot leave a child of pre-school age unsupervised. Polish law contains a number of parental obligations regulated both on the grounds of family and administrative law. Such obligations are for example the fulfillment of their children's obligation to study or given all compulsory vaccinations or hospital treatment to the child.

\subsection{Exercise of parental custody - Issues of parents living together or alone}

We now outline the possibilities of parents living alone and together and its impact on parental custody. It is a general rule that parents living together exercise parental rights and obligations together. Parental rights and responsibilities can be exercised by both parents in Slovakia. Minor children are under parental custody or guardianship in Hungary. In the case of a child born in marriage, parental custody is established in both paternal and maternal positions by birth. Cooperation between parents is essential to promote the proper physical, mental, and moral development of the child, regardless of whether the parents live together or separately. However, joint decisions do not always manifest if only one parent exercises parental custody of the joint minor child(ren) after the separation of the parents. In such cases, the parent living separately and apart shall exercise the joint right of decision-making only in respect of the major issues relating to the child's well-being. In Croatia, parents exercise parental responsibility jointly and by agreement until a contrary agreement is arrived at by parents or a judicial decision is adopted on this issue. After the termination of the family union, the parent living with the child exercises parental responsibility autonomously when no agreement pertaining to joint parental care has been arrived at in the course of court proceedings. A parent who does not live with the child and has not been able to arrive at an agreement on the exercise of parental responsibility has significantly limited rights. The Czech Civil Code stipulates that it is not relevant whether the child's parents are married or not, or live together or not. If the parents are not able to arrive at an agreement on important matters concerning the child, especially regarding the personal care of the child, the court can decide among three types of custody: individual custody by one parent or alternating or joint custody by both. The law provides for the suspension of the exercise of parental responsibility on the ground of immaturity or mental disorder on part of such a parent. In Poland, complex rules govern state intervention in the context of parental custody, in the form of limitation, suspension, and removal. Parental custody is limited by the family court through different orders such as orders for cooperation with a family helper, admission of the child into a day-care institution, or placement of the child in a foster parent or institution's custody. If there is a short-term obstacle preventing the exercise of parental custody, the court may suspend it temporarily. The court is obliged to remove parental custody from those parents who grossly neglect their child or abuse their parental authority (by 
using violence against the child), or if they pose a permanent obstacle to exercising such authority. Parents can be deprived of their parental authority if they show no interest in the child after (s)he has become a foster child. Parental custody expires if a parent becomes incapacitated. In Serbia, if the parents are not married, the mother automatically acquires parental rights from the moment of the birth of the child and the father acquires rights when paternity is established. The parent who does not exercise parental rights has the right and duty to contact and maintain a personal relationship with the child and have a say on the issues that significantly influence the child's life, such as significant medical interventions, a change in the child's residence, and disposal of the child's property. When parents do not live together, they may exercise their rights jointly or independently. One parent exercises the parental right alone based on a court decision when the parents do not live together. The parent who does not exercise parental rights has a right and duty to maintain the child. In Slovenia, parents exercise parental care jointly and consensually, and this rule applies to parents who live together and alone. Despite the separation, both parents exercise parental care unless it has been limited or withdrawn. If the parents no longer live together, they must agree on the care and upbringing of their joint children following their best interests. When the court dissolves a marriage based on a divorce petition filed by one of the spouses, it also decides on the custody, upbringing, and maintenance of the children living together and on their contact with their parents.

The table below presents a summary of the exercise of parental responsibility

\begin{tabular}{|c|l|}
\hline Country & \multicolumn{1}{|c|}{ Summary of the exercise of parental responsibility } \\
\hline Slovakia & $\begin{array}{l}\text { Rights and responsibilities belong to both parents. } \\
\text { In case of a dispute, the court can decide on parental custody. }\end{array}$ \\
\hline Hungary & $\begin{array}{l}\text { Rights and responsibilities belong to both parents. } \\
\text { If parents no longer live together, they must agree on the care and upbringing } \\
\text { of their children with due regard for the child's best interests. } \\
\text { In case of a dispute, the court can decide on parental custody. }\end{array}$ \\
\hline Croatia & $\begin{array}{l}\text { Rights and responsibilities belong to both parents. } \\
\text { In case of a dispute, the court can decide on parental custody. }\end{array}$ \\
\hline Czech & $\begin{array}{l}\text { Rights and responsibilities belong to both parents. } \\
\text { In case of a dispute, the court can decide on parental custody. }\end{array}$ \\
\hline Poland & $\begin{array}{l}\text { Rights and responsibilities belong to both parents. } \\
\text { Possible state intervention concerning parental custody. }\end{array}$ \\
\hline
\end{tabular}




\begin{tabular}{|c|l|}
\hline Country & \multicolumn{1}{|c|}{ Summary of the exercise of parental responsibility } \\
\hline Serbia & $\begin{array}{l}\text { Rights and responsibilities belong to both parents. } \\
\text { If the parents are not married, the mother automatically acquires parental } \\
\text { rights. } \\
\text { If the parents do not live together, joint or independent parental custody } \\
\text { applies. }\end{array}$ \\
\hline Slovenia & $\begin{array}{l}\text { Rights and responsibilities belong to both parents. } \\
\text { If the parents no longer live together, they must agree on the care and up- } \\
\text { bringing of their children with due regard for the child's best interests. }\end{array}$ \\
\hline
\end{tabular}

\subsection{The child's religion and issues concerning the national identity of the child}

It is also an interesting question on the content of parental responsibility, whether the parents or the State are entitled to determine the child's religion and national identity. In Hungary, the State is not allowed to influence the religion of a child. Only the parents can handle this issue. We saw in the part on adoption, that in the Hungarian system, the parties participating in the adoption process shall take into account the child's family ties, nationality, religion, mother tongue and cultural background. In Slovakia, parents have a right to raise their children in accordance with their religious and philosophical beliefs and the obligation to provide the family with a peaceful and safe environment. The Polish Constitution grants parents primacy in raising their children in keeping with their conscience and convictions. This applies to religious and moral upbringing (art. 48(1) and art.53 (3) of the Polish Constitution). Parents are entitled to freely choose schools for their children. In Croatia, the child has the right to freedom of conscience and religion, just like any other person. If the parents wish to choose or change the religious affiliation of the child, they shall do that together when they share parental responsibility. In the Croatian legal system, the rights of children belonging to national minorities are protected by the Constitutional Act on Rights of National Minorities, which guarantees the right to use a language, the preservation of cultural identity, the right to education and upbringing in their mother tongue, and the rights to express their own faith and found religious communities. The Serbian Constitution stipulates thus: "The Republic of Serbia shall promote understanding, recognition and respect of diversity arising from specific ethnic, cultural, linguistic or religious identity of its citizens through measures applied in education, culture and public information." In line with this regulation, parents have the right to provide a child with education that is in accordance with their religious and ethical beliefs. The Slovenian Constitution also gives the parents the right to provide the children a religious and moral upbringing in line with their beliefs. The religious and moral guidance given to children must be appropriate to their age and maturity, and consistent with their free conscience and religious and other beliefs or convictions. The Freedom of Religion Act also gives 
parents the right to educate their children in line with their religious beliefs. According to this law, a child who has reached the age of 15 years, has a right to make his or her own decisions relating to religious freedom.

The following table outlines the issues concerning a child's religion

\begin{tabular}{|c|l|}
\hline Country & \multicolumn{1}{|c|}{ Issues concerning a child's religion } \\
\hline Hungary & The state cannot influence the religion of the child, only parents can. \\
\hline Slovakia & $\begin{array}{l}\text { Parents may raise their children in line with their religious and philosophical } \\
\text { beliefs. }\end{array}$ \\
\hline Poland & $\begin{array}{l}\text { Parents have primacy in raising their children in accordance with their con- } \\
\text { science and convictions. } \\
\text { Parents are entitled to freely choose schools for their children. }\end{array}$ \\
\hline Croatia & $\begin{array}{l}\text { The child has the right to freedom of conscience and religion. } \\
\text { If the parents wish to choose or change the religious affiliation of the child, } \\
\text { they shall do so together when they share parental responsibility. } \\
\text { The rights of children belonging to national minorities are protected by the } \\
\text { Constitutional Act on the Rights of National Minorities. }\end{array}$ \\
\hline Serbia & $\begin{array}{l}\text { Parents have a right to provide their children with education that is in line } \\
\text { with their religious and ethical beliefs. }\end{array}$ \\
\hline Slovenia & $\begin{array}{l}\text { Parents have the right to provide their children religious and moral upbringing } \\
\text { in line with their beliefs. } \\
\text { A child who has attained the age of } 15 \text { years, has the right to make his or her } \\
\text { own decisions vis-à-vis religious freedom. }\end{array}$ \\
\hline
\end{tabular}

\subsection{Direct family relations with special regard for maintenance}

In this part, we examine direct family relationships or kinship connections among parents and their children and the situation of foster children. We present a comparison - whenever possible - of the definition of stepparent and foster parent. We can see the detailed regulations on the system of foster care in some countries. The stepfather and stepmother are expressly referred to in the Croatian Family Act only as people who mutually enjoy the right to maintenance with the child under the conditions provided for by the law. Like other family members who live with the child, they may, upon the parents' consent, take day-to-day decisions concerning the child. In Slovakia, foster care is addressed in the Family Act, but the regulation can be found on the boundaries of private and public law. Consequently, the legal institution has private and public law features. In Serbian law, the stepparent (the blood parent's new spouse - same definition as in Hungary) has the obligation to maintain 
a minor stepchild during and after the termination of marriage by the death of the biological parent (not if the marriage between his/her parent and stepmother or stepfather has ceased by annulment or divorce). A stepparent has the right to maintenance from his/her mature stepchild if such a stepparent cannot work and lacks sufficient means of maintenance in proportion to their stepchild's capacities. A stepparent does not have a right to maintenance if it would amount to an injustice to the stepchild. The definitions in the Slovenian law align with the terminology in place in other countries: a new partner of a de facto partner is a foster parent, whereas the blood parent's new spouse is the stepparent. Family solidarity implies an obligation for the spouse or extramarital partner of the partner to support the child of his/her spouse or extramarital partner unless the child's parent is capable of supporting the child. This obligation has a subsidiary nature as it can be imposed only if the child cannot be maintained by their parents. The maintenance obligation of a spouse or extramarital partner of a child's parent will cease with the dissolution of marriage or extramarital union with the child's parent unless the dissolution is the result of the death of the child's mother or father. In such cases, the surviving spouse or extramarital partner (stepparent) must support the child, if they were living together at the time of death. In the Czech Republic, foster care is provided in foster families or through institutional childcare homes. It replaces the care exercised by parents when they are unable to exercise it. The strategic goal of placing a child in foster care is to bring him or her back to the family after he or she has received support, and new conditions conducive for reintegration are created. If this is not achieved, parental authority may be removed from the biological parents and the child may be transferred for adoption. The formal basis for placing a child in foster care is a court order. It limits and sometimes suspends parental authority, but seldom removes parental authority altogether. Foster parents are commonly observed to consider the foster child their own (quasi-adoptive motivation), and not a child who has a family to which he or she should return. This causes problems between parents and their children and hampers family integration. In Poland, foster care is regulated by the Family and Guardianship Code and the Act on Family Assistance and Foster Care. Foster care is provided through foster families and institutional childcare homes. It replaces the care exercised by parents when they are unable to offer it. The strategic goal of placing a child in foster care is to bring him/her back to the family after he or she has received support, and new conditions conducive for reintegration are created. If this is not achieved, parental authority may be removed from the biological parents and the child may be transferred for adoption. The formal basis for placing a child in foster care is a court order. In foster families, foster parents are commonly observed to consider the foster child as their own child and not as a child who has a family to which he or she should return, which can cause problems in practice. The Hungarian Civil Code attaches great importance to the child's "direct family relationships." This is reflected in the rule that entitles a child's stepparent or foster parent to exercise certain parental custody rights in the context of care and upbringing of the child. A person with an actual family relationship with the child is usually the new 
spouse (stepparent) or de facto partner (foster parent) of the parent exercising parental custody, who is often an active participant in the child's upbringing and care. In the Hungarian context, a foster parent is a person who permanently and for a long period of time takes care for a minor child in his or her own household, and he or she is not a biological, adoptive, or stepparent of the child. The importance of the actual family relationship is strengthened by the provision in the Civil Code, which expands the scope of the right to maintain contact with the child to the stepparent, foster parent, former guardian, and the parent whose presumption of paternity for the child has been overturned by the court, provided that the child concerned was raised in their household for a longer period of time. The sudden interruption of the intimate relationship between the child and the man he loves as a father can seriously damage the spiritual development and emotional security of the child. This may be particularly important in cases where no one takes the place of the father in the life of the child after the presumption of paternity has been rebutted.

The table below presents issues pertaining maintenance and direct family relationships

\begin{tabular}{|c|l|}
\hline Country & \multicolumn{1}{|c|}{ Maintenance and direct family relationships } \\
\hline Croatia & $\begin{array}{l}\text { The stepfather and stepmother mutually enjoy the right to maintenance with } \\
\text { the child. } \\
\text { They take day-to-day decisions concerning the child. }\end{array}$ \\
\hline Slovakia & $\begin{array}{l}\text { The issue of foster care is addressed in the Family Act. } \\
\text { The legal institution has private and public law features. }\end{array}$ \\
\hline Serbia & $\begin{array}{l}\text { Stepparent: The blood parent's new spouse. } \\
\text { Obligation to maintenance a minor stepchild. } \\
\text { A stepparent does not have the right to maintenance if it would amount to an } \\
\text { injustice for the stepchild. }\end{array}$ \\
\hline Slovenia & $\begin{array}{l}\text { A new partner of the de facto partner is the foster parent, whereas the blood } \\
\text { parent's new spouse is the stepparent. } \\
\text { Principle of family solidarity. } \\
\text { Maintenance obligation has a subsidiary nature. }\end{array}$ \\
\hline $\begin{array}{c}\text { Czech } \\
\text { Republic }\end{array}$ & $\begin{array}{l}\text { Foster care is provided in the family (foster families). } \\
\text { Institutional form (childcare homes). } \\
\text { In foster families, foster parents are commonly observed to consider the foster } \\
\text { child their own child (quasi-adoptive motivation). }\end{array}$ \\
\hline Poland & $\begin{array}{l}\text { Foster families. } \\
\text { Institutional form (childcare homes). } \\
\text { Formal basis for placing a child in foster care takes place by a court order. }\end{array}$ \\
\hline
\end{tabular}




\begin{tabular}{|l|l|}
\hline Country & \multicolumn{1}{c|}{ Maintenance and direct family relationships } \\
\hline Hungary & $\begin{array}{l}\text { Great importance to the child's “direct family relationships." } \\
\text { A child's stepparent or foster parent can exercise certain parental custody } \\
\text { rights in the context of care and upbringing of the child. } \\
\text { Stepparent: New spouse. } \\
\text { Foster parent: De facto partner. }\end{array}$ \\
\hline
\end{tabular}

